\title{
Glucose and glutamine metabolism in pre-attachment cattle embryos in relation to sex and stage of development
}

\author{
G. J. Tiffin*, D. Rieger $\dagger$, K. J. Betteridge, B. R. Yadav $\ddagger$ and W. A. King \\ Department of Biomedical Sciences, University of Guelph, Guelph, Ontario, Canada, N1G 2W1
}

\begin{abstract}
Summary. Individual Day-7 embryos (morulae to expanded blastocysts) were incubated with radiolabelled substrates and karyotyped to determine the sex. In Exp. 1, embryos were incubated for $3 \mathrm{~h}$ with $\mathrm{D}-\left[1-{ }^{14} \mathrm{C}\right]$ glucose, as a measure of the activity of the pentose-phosphate pathway (PPP) and $\mathrm{D}-\left[5-{ }^{3} \mathrm{H}\right]$ glucose, as a measure of total glucose metabolism. The labelled products ${ }^{14} \mathrm{CO}_{2}$ and ${ }^{3} \mathrm{H}_{2} \mathrm{O}$ were collected throughout the measurement period. Total glucose metabolism in male embryos was twice that in female embryos and increased between the morula and expanded-blastocyst stages. Relative to total glucose metabolism, PPP activity was four times greater in female than in male embryos. In Exp. 2, embryos were cultured with $\mathrm{D}-\left[1-{ }^{14} \mathrm{C}\right]$ glucose, and $\mathrm{L}-\left[3,4-{ }^{3} \mathrm{H}(\mathrm{N})\right]$ glutamine (a measure of Krebs cycle activity) in the presence of brilliant cresyl blue, a stimulator of the PPP. Glutamine metabolism increased from the morula to expanded-blastocyst stages. Relative to the metabolism of glutamine, the activity of the PPP was one-third greater in female than in male embryos.
\end{abstract}

Keywords: cattle; embryo; metabolism; development; sex

\section{Introduction}

The growth and development of early embryos requires considerable metabolic activity for the production of energy and for the synthesis of a variety of complex molecules. The relationship between development and a wide variety of aspects of metabolism has been studied in preimplantation mouse and rabbit embryos (see Kaye, 1986). Apart from one study of pig embryos (Flood \& Wiebold, 1988) and one of cattle embryos produced by in-vitro fertilization (Iwasaki et al., 1989), we found no information about the relationship between metabolism and development of embryos of domestic animals.

The relationship between the sex and metabolic activity of early embryos has received little study in any species, but should be of major interest for two reasons. First, even before the development of the testis in mice, rats and humans, male embryos develop faster than females (see Mittwoch, 1989). This difference must, in some way, be related to differences in the activity of one or more metabolic pathways between male and female embryos. Second is the more specific effect of sex on the activity of the pentose-phosphate pathway (PPP) which produces two major biosynthetic substrates, ribose-5phosphate, the precursor for the synthesis of nucleotides and nucleic acids, and NADPH, the major source of reducing equivalents for the synthesis of lipids and other complex molecules (Wood, 1985). The first and rate-limiting step of this pathway is catalysed by the enzyme glucose-6-phosphate dehydrogenase (G6PD) (Wood, 1985). The gene which codes for this enzyme is on the X chromosome (Chapman \& Shows, 1976) and thus there are 2 copies in female cells but only one in male

\footnotetext{
*Present address: Department of Obstetrics and Gynaecology, University of Western Ontario, London, Ontario, Canada, N6A 3K7

$†$ Reprint requests.

\$Present address: National Institute of Animal Genetics, National Bureau of Animal Genetic Resources, NDRICampus, Karnal-Haryana, 132001, India.
} 
cells. This inequality has no effect on the biochemical activity of mature females, because early in embryonic development one of the $\mathrm{X}$ chromosomes is inactivated (Lyon, 1961). However, between the time of activation of the embryonic genome and the onset of $\mathrm{X}$-inactivation, both $\mathrm{X}$ chromosomes in female embryos are potentially active and consequently the activity of several X-linked enzymes in broken-cell preparations from female mouse embryos has been shown to be twice that in male embryos (Monk, 1987; Monk \& Handyside, 1988). In intact mouse embryos, total glucose uptake (Gardner \& Leese, 1987) and reductive potential (Williams, 1986) tend to be higher in female embryos than in males.

We have measured the metabolic activity of individual cattle blastocysts using single radiolabelled glycolytic substrates and shown that the Krebs cycle, PPP and Embden-Meyerhof pathway (EMP) are active and that pyruvate kinase activity is blocked (Rieger \& Guay, 1988). The technique has since been elaborated to permit the simultaneous measurement of any 2 of these pathways in individual embryos by using one ${ }^{14} \mathrm{C}$-labelled substrate and one ${ }^{3} \mathrm{H}$-labelled substrate together (Rieger et al., 1989). The activity of the pathways can be related to each other, which is particularly important in studying the PPP because its activity can be related to total glucose metabolism, or to the activity of the Krebs cycle, which involves no known X-linked enzymes.

The study presented here used the double-label technique to determine the effect of sex and stage of development on the activities of the EMP and Krebs cycle and on the absolute and relative activity of the PPP in individual cattle embryos. In Exp. 1, the basal activities of the PPP and the EMP were measured. In Exp. 2, the activities of the PPP and the Krebs cycle were measured in the presence of brilliant cresyl blue (BCB), an oxidizing vital stain which stimulates the PPP (Williams, 1986). A preliminary report of some of the results presented here has been published as an abstract (Tiffin et al., 1990).

\section{Materials and Methods}

Embryo collection. Embryos were collected at Day 7 (Day $0=$ day of first detected oestrous behaviour) from groups of 36 superovulated Holstein heifers, as described by Rieger et al. (1988). The embryos were isolated from the collection medium and classified according to the morphological criteria of Elsden et al. (1978). Only embryos judged to be morphologically normal were used. Embryos classed as morulae included those uncompacted and compacted, but not obviously retarded. Early blastocysts showed some indication of the appearance of a blastocoele, while those classed as midblastocyst stage had a clearly defined blastocoele and an inner-cell mass. Expanded blastocysts were larger in diameter and had thinner zonae pellucidae.

Culture medium. The basic culture medium was bicarbonate-buffered Ham's F-10 (Flow Laboratories, McLean, VA, USA), which contains $6.11 \mathrm{~mm}$ glucose and $1 \mathrm{~mm}$ glutamine in addition to a wide variety of other amino acids, vitamins, fatty acids and pyruvate. This was supplemented with $25 \mathrm{~mm}-N-2$-hydroxyethylpiperazine- $N^{\prime}-2-$ ethanesulphonic acid (Hepes: Flow Laboratories), $0.4 \%$ bovine serum albumin (BSA: Sigma, St Louis, MO, USA), $100 \mathrm{iu}$ penicillin/ml and $100 \mu \mathrm{g}$ streptomycin/ml (Gibco Laboratories, Grand Island, NY, USA). Before measuring their metabolism, the embryos were washed 4 times in culture medium. For Exp. 2, the final wash contained 0.02 mg $\mathrm{BCB} / \mathrm{ml}$ (Sigma).

Radiolabelled substrates. For Exp. 1, D- $\left[1-{ }^{14} \mathrm{C}\right] \mathrm{glucose}$ (sp. act. $56.6 \mathrm{mCi} / \mathrm{mmol}$ : New England Nuclear, Boston, USA) was mixed with $\mathrm{D}-\left[5-{ }^{3} \mathrm{H}\right]$ glucose $(21 \cdot 1 \mathrm{Ci} / \mathrm{mmol}$ : Amersham International, Amersham, UK). For Exp. 2, D- $\left[1-{ }^{14} \mathrm{C}\right.$ glucose was mixed with $\mathrm{L}-\left[3,4-{ }^{3} \mathrm{H}(\mathrm{N})\right]$ glutamine $(52 \cdot 2 \mathrm{Ci} / \mathrm{mmol}$ : Amersham International). The mixtures were dried under nitrogen and taken up in culture medium to give nominal concentrations of $0 \cdot 25 \mu \mathrm{Ci} / \mu \mathrm{l}$ for each labelled substrate.

Metabolic measurement. The culture apparatus consisted of inner wells cut from multiwell strips (Lux, 5250: Miles Laboratories, Napierville, IL, USA) placed in $400 \mu \mathrm{l}$ of $25 \mathrm{~mm}-\mathrm{NaHCO}_{3}$ within wells of larger multiwell plates (Falcon 3047: Becton-Dickinson, Lincoln, NJ, USA) as described by Rieger \& Guay (1988). Individual embryos were taken up in $2 \mu \mathrm{l}$ of the final wash and placed in the inner well of the culture apparatus, with $2 \mu \mathrm{l}$ of the appropriate mixture of radiolabelled substrates, to give a total culture volume of $4 \mu 1$. Three sham preparations, containing all reagents, but no embryo, were included for each set of treatments, and served as control for all nonspecific measurements of activity due to machine background, chemiluminescence, bacterial contamination or spontaneous breakdown of the labelled substrate. The plates were equilibrated under $5 \% \mathrm{CO}_{2}$ in air for $15 \mathrm{~min}$ before being sealed with self-adhesive polyester film (Falcon 3073: Becton-Dickinson) and incubated for 1 (Exp. 2) or $3 \mathrm{~h}$ (Exp. 1). At the end of the culture period, $50 \mu \mathrm{l}$ of $1.0 \mathrm{M}-\mathrm{NaOH}$ was injected through the polyester film into the outer well via a 25-gauge 
needle to convert the dissolved $\mathrm{CO}_{2}$ and bicarbonate into carbonate. The film was then removed and $200 \mu \mathrm{l}$ of the contents of the outer bath was aspirated, mixed with $13 \mathrm{ml}$ scintillation fluid (HP/b: Beckman Instruments, Fullerton, CA, USA) and radioactivity was measured for $5 \mathrm{~min}$ in a liquid scintillation counter (Packard Instrument Co., Downers Grove, IL, USA) programmed for automatic dual-label correction to disintegrations per minute (d.p.m.). The total d.p.m. of labelled substrate was determined by mixing $2 \mu \mathrm{l}$ of the labelled substrate solution with $400 \mu \mathrm{l}$ $25 \mathrm{~mm}-\mathrm{NaHCO}_{3}$ and counting in the same way.

Estimation of product recovery. The efficiency of recovery of the radiolabelled products was estimated as described by Rieger \& Guay (1988). Briefly, known amounts of $\mathrm{NaH}^{14} \mathrm{CO}_{3}$ and ${ }^{3} \mathrm{H}_{2} \mathrm{O}$ (New England Nuclear) were taken up in 4- $\mu \mathrm{l}$ droplets of culture medium and cultured for $0-3 \mathrm{~h}$, as for the embryos. At the end of each period, the outer bath was aspirated, mixed with scintillation fluid and radioactivity was measured. The maximum proportions of both labels were recovered within $30 \mathrm{~min}$, yielding recovery correction factors of 1.37 for ${ }^{3} \mathrm{H}_{2} \mathrm{O}$ and 1.41 for ${ }^{14} \mathrm{CO}_{2}$.

Calculation of substrate metabolism. The amount of each substrate metabolized by each embryo was calculated in a fashion similar to that previously described for single-labelled substrates (Rieger \& Guay, 1988). For each labelled substrate, the mean d.p.m. for the sham preparations was subtracted from the d.p.m. for each embryo. The difference was divided by the total d.p.m. of labelled substrate added and multiplied by the total quantity of substrate in $4 \mu \mathrm{l}$ of medium and by the appropriate recovery correction factor.

Cytogenetic analysis. Immediately after the metabolic measurement, the embryos were cultured individually in $0.5 \mathrm{ml}$ of medium containing $0.05 \mu \mathrm{g}$ Colcemid (Gibco) $/ \mathrm{ml}$ for $4-8 \mathrm{~h}$ and then fixed individually on slides as described by King et al. (1979). The slides were stained in a $4 \%$ Giemsa solution for $3 \mathrm{~min}$ and the metaphase spreads located and counted under a compound microscope at low power. The chromosomes were examined at $\times 1000$ magnification and the sex was diagnosed as female by the presence of two $\mathrm{X}$ chromosomes in at least one intact metaphase, or as male by the observation of a $Y$ chromosome. Preparations for which a definite conclusion regarding the sex of the embryo could not be reached were further stained for centromeric heterochromatin (Sumner, 1972) and examined again.

Statistical analysis. The distributions of embryos by sex (male, female, not determined) and stage of development (morula and early, mid-, and expanded blastocyst) in each experiment were evaluated by $\chi^{2}$ analysis. Logarithmic values of the metabolic measurements were first evaluated by two-way analyses of variance (sex by stage of development) and group means across each factor compared by Duncan's multiple-range tests.

\section{Results}

In Exp. 1, the classifications by sex and stage of development were unrelated (Table $1, P=0 \cdot 29$ ). The relationship between sex and stage approached statistical significance $(P=0.06)$ in Exp. 2, but this was entirely due to the distribution of embryos of undetermined sex because there was no relationship between classifications when only the sexed embryos were considered $(P=0.62)$.

Table 1. Numbers of cattle embryos, by sex and stage of development, in Exps 1 and 2

\begin{tabular}{|c|c|c|c|c|}
\hline \multirow[b]{2}{*}{ Developmental stage } & \multicolumn{3}{|c|}{ Sex } & \multirow[b]{2}{*}{ Total } \\
\hline & Male & Female & Not determined & \\
\hline \multicolumn{5}{|l|}{ Exp. 1} \\
\hline Morula & $10(8 \cdot 3)$ & $5(4 \cdot 1)$ & $36(29 \cdot 8)$ & $51 \quad(42 \cdot 1)$ \\
\hline Early blastocyst & $3(2 \cdot 5)$ & $3(2.5)$ & $15(12 \cdot 4)$ & $21 \quad(17.4)$ \\
\hline Midblastocyst & $1(0 \cdot 8)$ & $5(4 \cdot 1)$ & $19(15 \cdot 7)$ & $25(20 \cdot 7)$ \\
\hline Expanded blastocyst & $2(1 \cdot 7)$ & $1(0 \cdot 8)$ & $21(17 \cdot 4)$ & $24(19 \cdot 8)$ \\
\hline Total & $16(13 \cdot 2)$ & $14(11 \cdot 6)$ & $91(75 \cdot 2)$ & $121(100)$ \\
\hline \multicolumn{5}{|l|}{ Exp. 2} \\
\hline Morula & $3(5 \cdot 6)$ & $2(3 \cdot 7)$ & $9(16 \cdot 7)$ & $14 \quad(25.9)$ \\
\hline Early blastocyst & $7(13 \cdot 0)$ & $8(14 \cdot 8)$ & $3(5 \cdot 6)$ & $18 \quad(33 \cdot 3)$ \\
\hline Midblastocyst & $5(9 \cdot 3)$ & $2(3 \cdot 7)$ & $5(9 \cdot 3)$ & $12(22 \cdot 2)$ \\
\hline Expanded blastocyst & $1(1.9)$ & $2(3 \cdot 7)$ & $7(13 \cdot 0)$ & $10(18 \cdot 5)$ \\
\hline Total & $16(29 \cdot 6)$ & $14(25 \cdot 9)$ & $24(44 \cdot 4)$ & $54(100)$ \\
\hline
\end{tabular}

Numbers in parentheses are percentages of total number of embryos used in each experiment. 
For Exp. 1 (Table 2) analysis of variance for the metabolism of D- $\left[1-{ }^{14} \mathrm{C}\right] \mathrm{glucose}$ indicated that the overall effect of sex approached significance $(P=0.06)$, but there was no effect of stage of development $(P=0.29)$ or interaction between sex and stage $(P=0.35)$ and no significant differences among individual group means. For the metabolism of $\mathrm{D}-\left[5-{ }^{3} \mathrm{H}\right]$ glucose, there were highly significant $(P<0.01)$ effects of both sex and stage, but no effect of interaction $(P=0.51)$. The mean metabolism of $\mathrm{D}-\left[5{ }^{3} \mathrm{H}\right]$ glucose by male embryos was significantly greater than that by female embryos and increased with development from the morula to expanded blastocyst stage. There was a significant effect of $\operatorname{sex}(P=0.02)$ on the ratio of $\mathrm{D}-\left[1-{ }^{14} \mathrm{C}\right]$ glucose to $\mathrm{D}-\left[5-{ }^{3} \mathrm{H}\right]$ glucose metabolism and a strong tendency toward a significant effect of stage $(P=0.07)$, but no effect of interaction $(P=0 \cdot 85)$. The mean ratio was not different among the developmental stages, but, although not statistically different, was 4 times greater in females than in males.

Table 2. Glucose metabolism by Day-7 cattle embryos during a 3-h incubation at $37^{\circ} \mathrm{C}$ (Exp. 1)

\begin{tabular}{|c|c|c|c|c|}
\hline \multirow[b]{2}{*}{ Group } & \multirow{2}{*}{$\begin{array}{l}\text { No. of } \\
\text { embryos }\end{array}$} & \multicolumn{2}{|c|}{$\begin{array}{l}\text { Substrate metabolized } \\
\text { (pmoles/embryo/3 h) }\end{array}$} & \multirow{2}{*}{$\begin{array}{c}\text { Ratio } \\
\text { D- }\left[1-1^{14} \text { C }\right] \text { glucose } \\
\left.\text { D-[5- }-^{3} \mathrm{H}\right] \text { glucose }\end{array}$} \\
\hline & & $\mathrm{D}-\left[1-{ }^{14} \mathrm{C}\right]$ glucose & D- $\left[5-{ }^{3} \mathrm{H}\right]$ glucose & \\
\hline \multicolumn{5}{|l|}{ By sex } \\
\hline Male & 16 & $7 \cdot 02 \pm 1 \cdot 15$ & $35.00 \pm 3.93^{\mathrm{a}}$ & $0.25 \pm 0.06$ \\
\hline Female & 14 & $5.55 \pm 0.97$ & $15 \cdot 40 \pm 3 \cdot 28^{\mathrm{ab}}$ & $0.99 \pm 0.45^{\mathrm{f}}$ \\
\hline Not determined & 91 & $4 \cdot 10 \pm 0 \cdot 31$ & $28.75 \pm 1.98^{b}$ & $0.21 \pm 0.03^{\mathrm{f}}$ \\
\hline \multicolumn{5}{|l|}{ By stage } \\
\hline Morula & 51 & $4.34 \pm 0.51$ & $22 \cdot 32 \pm 2.07^{\mathrm{cd}}$ & $0.30 \pm 0.05$ \\
\hline Early blastocyst & 21 & $3.68 \pm 0.53$ & $29.62 \pm 3.00^{\mathrm{c}}$ & $0.21 \pm 0.06$ \\
\hline Midblastocyst & 25 & $5.28 \pm 0.74$ & $27.26 \pm 3.72^{\mathrm{e}}$ & $0.55 \pm 0.27$ \\
\hline Expanded blastocyst & 24 & $5 \cdot 53 \pm 0.70$ & $39 \cdot 56 \pm 4.82^{\text {de }}$ & $0.18 \pm 0.03$ \\
\hline Total & 121 & $4.66 \pm 0.31$ & $28.06 \pm 1.67$ & $0.31 \pm 0.06$ \\
\hline
\end{tabular}

All values are means \pm s.e.m.

abedef Values with the same superscript letter are significantly different $(P \leqslant 0.05)$.

The effect of BCB on the activity of the PPP can be appreciated by comparing the metabolism of $\mathrm{D}-\left[1-{ }^{14} \mathrm{C}\right]$ glucose in the presence (Exp. 2, Table 3) and absence (Exp. 1) of the stimulator. In Exp. 2, the overall mean metabolism of $\mathrm{D}-\left[1-{ }^{14} \mathrm{C}\right]$ glucose was more than 5 times greater than in Exp. 1 (8.69 pmol/embryo per $\mathrm{h}$ vs. $1.55 \mathrm{pmol} / \mathrm{embryo}$ per $\mathrm{h})$.

Analysis of variance of $\mathrm{D}-\left[1-{ }^{14} \mathrm{C}\right]$ glucose metabolism in Exp. 2 indicated that there were no overall effects of sex $(P=0.53)$, stage of development $(P=0 \cdot 36)$, or interaction $(P=0.51)$ and no significant differences among individual group means. There were also no effects of sex or interaction on the metabolism of $L-\left[3,4-{ }^{3} \mathrm{H}(\mathrm{N})\right]$ glutamine, but there was a highly significant effect of stage of development $(P<0.01)$. The mean metabolism of this substrate did not differ among the morula, early, and midblastocyst stages, but was significantly greater in expanded blastocysts than in the earlier stages. For the ratio of $\mathrm{D}-\left[1-^{14} \mathrm{C}\right]$ glucose to $\mathrm{L}-\left[3,4-{ }^{3} \mathrm{H}(\mathrm{N})\right]$ glutamine metabolism, there was, similarly, no overall effect of $\operatorname{sex}(P=0.20)$ or interaction $(P=0 \cdot 21)$, but there was a significant effect of stage $(P=0.04)$. The ratio decreased significantly between the morula and expanded blastocyst stages, was almost twice as great in female embryos than in those of undetermined sex, and more than one-third greater in females than in males, although the last difference was not statistically significant.

The inability to determine the sex of the embryo by karyotyping was usually due to a lack of cells in metaphase and, less frequently, to chromosomes that were poorly spread or otherwise unanalysable. The success rate for sex determination more than doubled from $24 \cdot 7 \%$ in Exp. 1 to $55.6 \%$ in Exp. 2, but it is unclear whether this was due to an improvement in technique, or to the 
Table 3. Glucose and glutamine metabolism by Day-7 cattle embryos during a $1-\mathrm{h}$ incubation at $37^{\circ} \mathrm{C}$ in the presence of $0.01 \mathrm{mg}$ brilliant cresyl blue/ml (Exp. 2)

\begin{tabular}{|c|c|c|c|c|}
\hline \multirow[b]{2}{*}{ Group } & \multirow{2}{*}{$\begin{array}{l}\text { No. of } \\
\text { embryos }\end{array}$} & \multicolumn{2}{|c|}{$\begin{array}{l}\text { Substrate metabolized } \\
\text { (pmol/embryo per } h \text { ) }\end{array}$} & \multirow{2}{*}{$\begin{array}{c}\text { Ratio } \\
\text { D- }\left[1-{ }^{14} \mathrm{C}\right] \mathrm{glucose} \\
\mathrm{L}-\left[3,4-{ }^{3} \mathrm{H}(\mathrm{N})\right] \text { glutamine }\end{array}$} \\
\hline & & $D-\left[1-{ }^{14} C\right]$ glucose & $\mathrm{L}-\left[3,4-{ }^{3} \mathrm{H}(\mathrm{N})\right]$ glutamine & \\
\hline \multicolumn{5}{|l|}{ Sex } \\
\hline Male & 16 & $9.40 \pm 1.52$ & $0.55 \pm 0 \cdot 11$ & $29.54 \pm 9.75$ \\
\hline Female & 14 & $8.47 \pm 0.86$ & $0.41 \pm 0.07^{\mathrm{a}}$ & $40.39 \pm 11.95^{\mathrm{e}}$ \\
\hline Not determined & 24 & $8.35 \pm 0.57$ & $1.44 \pm 0.48^{\mathrm{a}}$ & $21 \cdot 31 \pm 4.82^{\circ}$ \\
\hline \multicolumn{5}{|l|}{ Stage } \\
\hline Morula & 14 & $10.07 \pm 1.66$ & $0.55 \pm 0.09^{b}$ & $30 \cdot 24 \pm 11 \cdot 10^{f}$ \\
\hline Early blastocyst & 18 & $7.41 \pm 0.57$ & $0.48 \pm 0.09^{c}$ & $33.68 \pm 9.52^{8}$ \\
\hline Midblastocyst & 12 & $8.37 \pm 0.70$ & $0.51 \pm 0.14^{\mathrm{d}}$ & $28.93 \pm 5.74^{\mathrm{h}}$ \\
\hline Expanded blastocyst & 10 & $9.46 \pm 1.29$ & $2.66 \pm 1.04^{\mathrm{bcd}}$ & $17 \cdot 26 \pm 7 \cdot 04^{\mathrm{ggh}}$ \\
\hline Total & 54 & $8.69 \pm 0.55$ & $0.91 \pm 0.22$ & $28.69 \pm 4.61$ \\
\hline
\end{tabular}

All values are means \pm s.e.m.

Values with the same superscript letter are significantly different $(P \leqslant 0.05)$.

shorter measurement period in Exp. 2. The metabolism of $D-\left[1-{ }^{14} \mathrm{C}\right]$ glucose and $\mathrm{D}-\left[5-{ }^{3} \mathrm{H}\right] \mathrm{glucose}$ by embryos in which the sex could not be determined was not different from that of either the male or the female embryos. However, in Exp. 2, the metabolism of $L-\left[3,4-{ }^{3} \mathrm{H}(\mathrm{N})\right]$ glutamine by the embryos of undetermined sex was 3 times greater than that for sexed embryos.

\section{Discussion}

We have previously shown that much less ${ }^{14} \mathrm{CO}_{2}$ is released from $\mathrm{D}-\left[6-{ }^{14} \mathrm{C}\right]$ glucose than from D- $\left[1-{ }^{14} \mathrm{C}\right]$ glucose by Day-7 cattle embryos in Ham's F-10 medium immediately after collection (Rieger et al., 1989), or after $24 \mathrm{~h}$ of culture to the blastocyst stage (Rieger \& Guay, 1988). When such a relationship exists, Larrabee (1989) has suggested that the production of ${ }^{14} \mathrm{CO}_{2}$ from $D-\left[1-{ }^{14} \mathrm{C}\right]$ glucose can be considered to arise exclusively from processing through the PPP. Similarly, O'Fallon \& Wright (1987) have shown that ${ }^{14} \mathrm{CO}_{2}$ release from $\mathrm{D}-\left[6-{ }^{14} \mathrm{C}\right]$ glucose by mouse embryos is minimal in the presence of lactate or pyruvate and have taken the production of ${ }^{14} \mathrm{CO}_{2}$ from $\mathrm{D}-\left[1-{ }^{14} \mathrm{C}\right] \mathrm{glucose}$ as a direct measure of PPP activity under those conditions. O'Fallon \& Wright (1987) suggested that the production of ${ }^{3} \mathrm{H}_{2} \mathrm{O}$ from $\mathrm{D}-\left[5-{ }^{3} \mathrm{H}\right]$ glucose reflects only the metabolism of glucose through the EMP and thus have calculated total glucose metabolism as the sum of this activity and the activity of the PPP. However, that portion of D- $\left[5-{ }^{3} \mathrm{H}\right]$ glucose-6phosphate that passes through the PPP and is not recycled will re-enter the EMP as $\left[2-{ }^{3} \mathrm{H}\right]-$ glyceraldehyde phosphate and the tritium is ultimately released as ${ }^{3} \mathrm{H}_{2} \mathrm{O}$. The very small quantities of ${ }^{14} \mathrm{CO}_{2}$ released from $\mathrm{D}-\left[6-{ }^{14} \mathrm{C}\right]$ glucose also indicate that recycling is limited. Consequently, we have taken the production of ${ }^{3} \mathrm{H}_{2} \mathrm{O}$ from $\mathrm{D}-\left[5-{ }^{3} \mathrm{H}\right]$ glucose as a measure of total glucose metabolism and calculated the proportion of glucose metabolism by the PPP as the ratio of the production of ${ }^{14} \mathrm{CO}_{2}$ from $\mathrm{D}-\left[1-{ }^{14} \mathrm{C}\right]$ glucose to the production of ${ }^{3} \mathrm{H}_{2} \mathrm{O}$ from $\mathrm{D}-\left[5-{ }^{3} \mathrm{H}\right]$ glucose.

In Exp. 1, metabolic activity of the embryos was measured in the absence of any metabolic stimulators and these measurements may then be considered to represent basal metabolic rates and be compared with studies of the embryos of other species. The results of this experiment indicate that the absolute activity of the PPP, evaluated by the metabolism of $D-\left[1-{ }^{14} \mathrm{C}\right]$ glucose alone, or relative to $\mathrm{D}-\left[5-{ }^{3} \mathrm{H}\right]$ glucose metabolism, does not change significantly during development of cattle embryos from the morula to expanded blastocyst stages. This is similar to the pattern observed in mouse embryos (O'Fallon \& Wright, 1986), but differs markedly from that in pig embryos (Flood \& Wiebold, 1988), where the metabolism of D- $\left[1-{ }^{14} \mathrm{C}\right]$ glucose increases significantly between the 
compacted morula and blastocyst stages. Using a histochemical technique, Iwasaki et al. (1989) were unable to detect G6PD in cattle morulae, which could simply reflect the relative insensitivity of this approach, although they did find significant G6PD activity up to the 8-cell stage.

The total metabolism of glucose, as measured by the metabolism of $\mathrm{D}-\left[5-{ }^{3} \mathrm{H}\right]$ glucose, increased significantly between the morula and expanded blastocyst stages, as has been shown for mouse (O'Fallon \& Wright, 1986) and pig (Flood \& Wiebold, 1988) embryos. Glucose uptake has similarly been shown to increase markedly between the 8-cell or morula and blastocyst stages in mouse (Gardner \& Leese, 1986, 1988) and human (Gott et al., 1990) embryos.

Total glucose metabolism was significantly greater in male embryos than in female embryos, which is, to our knowledge, a novel observation. The biochemical mechanism responsible for this difference is unknown, but it may have a physiological significance related to the different rates of development of male and female embryos. Within groups of Day-7 embryos collected from individual superovulated cattle, Avery (1989) found that embryos of the least advanced developmental stages are predominantly female, those of the most advanced stages are predominantly male, and the sexes are equally represented among those of intermediate stages. In a study of cattle embryos produced by in-vitro fertilization, those which cleaved early were predominantly male and those which cleaved late were predominantly female (B. Yadav, W. A. King \& K. J. Betteridge, unpublished observations). Although it is likely that the greater rate of total glucose metabolism by male embryos is related to their more rapid development, it is unclear which is the cause and which is the effect.

Gardner \& Leese (1987) have observed that glucose uptake (measured as disappearance from the medium) by female mouse embryos is $\sim 10 \%$ greater than that by male embryos. However, this observation is not necessarily contradictory to our own, because, whereas we measured only glucose metabolized through the PPP and the EMP, measurement of uptake would also include glucose which was incorporated into glycogen and other macromolecules. Ménézo \& K hatchadourian (1990) have suggested that the accumulation of glycogen is related to the 'two-cell block' to development in cultured mouse embryos. If the slower development of female embryos can be considered a milder form of impeded development, it would be interesting to know whether glycogen accumulation is greater in female than in male embryos.

The mean proportion of glucose metabolized through the PPP was much greater in female embryos than in males, which supports the hypothesis that G6PD activity is greater in female embryos because of the double gene dose. In 2- to 8-cell cattle embryos, Iwasaki et al. (1989) found no difference in G6PD activity between males and females, and no consistent relationship between G6PD activity and the number of $X$ chromosomes in polyploids. However, the embryonic genome in cattle is probably not expressed before the 16-cell stage (see Telford et al., 1990) and therefore the G6PD measured by Iwasaki et al. (1989) was almost certainly of maternal origin and would not have reflected the embryonic $\mathrm{X}$ chromosome dose.

We performed a number of small preliminary experiments (data not shown) to stimulate the PPP, in an effort to overcome any intracellular control mechanisms which might mask the difference between males and females. For example, we have previously shown that phenazine ethosulphate stimulates the activity of the PPP (Rieger \& Guay, 1988), but we have been unable to find an effective concentration that is not lethal to cattle embryos. Conversely, exposure of embryos to $0.01 \mathrm{mg} \mathrm{BCB} / \mathrm{ml}$ significantly increased the metabolism of $\mathrm{D}-\left[1-{ }^{14} \mathrm{C}\right]$ glucose while having no effect on the metabolism of $\mathrm{L}-\left[3,4-{ }^{3} \mathrm{H}(\mathrm{N})\right]$ glutamine and was not lethal to the embryos.

Although BCB clearly stimulated the metabolism of $\mathrm{D}-\left[1-{ }^{14} \mathrm{C}\right]$ glucose (compared with Exp. 1), the stimulation was equivalent in both sexes of embryos. In contrast to total glucose metabolism in Exp. 1, the metabolism of $\mathrm{L}-\left[3,4-{ }^{3} \mathrm{H}(\mathrm{N})\right]$ glutamine by unsexed embryos was significantly greater than that by sexed embryos. The reason for this is not evident, but we speculate that it may reflect a reduced viability of the unsexed embryos because it resembles the direct relationship that we have observed between glutamine metabolism and cell death in cryopreserved Day- 6.5 horse embryos (Rieger et al., in press). 
In the present study, $\mathrm{L}-\left[3,4-{ }^{3} \mathrm{H}(\mathrm{N})\right]$ glutamine metabolism was also significantly greater in expanded blastocysts than at earlier stages. The fact that total glucose metabolism was also greater in expanded blastocysts (in Exp. 1) suggests that there is a greater energy requirement at this stage. In rabbit embryos, development of the blastocoele is accompanied by marked increases in the energy requirements for $\mathrm{Na}^{+} / \mathrm{K}^{+}$ATPase (Benos \& Balaban, 1980), ouabain binding (Benos, 1981) and the content of $\mathrm{Na}^{+} / \mathrm{K}^{+}$ATPase $\alpha$-subunit and $\alpha$-subunit mRNA (Gardiner et al., 1990). There is no information available on $\mathrm{Na}^{+} / \mathrm{K}^{+}$ATPase in cattle embryos, but it is likely that much of the increased metabolic activity in expanded blastocysts is to provide the ATP required by this ion pump, for expansion of the blastocoele.

The activity of the PPP, in this case compared with the metabolism of $\mathrm{L}-\left[3,4-{ }^{3} \mathrm{H}(\mathrm{N})\right] \mathrm{glutamine}$ by the Krebs cycle, was greater in female embryos than in males, but, as in Exp. 1, the difference was not statistically significant. We have suggested (Rieger, 1984) that it should be possible to determine the sex of an intact embryo by measuring the activity of an X-linked enzyme during the period between the activation of the embryonic genome and $X$ inactivation. The enzymes in the embryos of the stages used in this study almost certainly arise from transcription and translation of the embryonic genome, rather than being of maternal origin (see Telford et al., 1990). X inactivation begins at the early blastocyst stage in mouse embryos (West, 1982) and $\sim 2$ days after the trophectoderm has differentiated in horse embryos (Romagnano et al., 1987). The time of X inactivation in cattle embryos is unknown, but we have observed cells having 2 active $\mathrm{X}$ chromosomes as late as Day 13 (W. A. King, unpublished).

In conclusion, we have shown that total glucose metabolism is greater in male Day-7 cattle embryos than in females, which may be related to more rapid development of male embryos. Total glucose metabolism and glutamine metabolism increased with development from the morula to the expanded blastocyst stage, which probably reflects the increased requirement for energy for $\mathrm{Na}^{+} / \mathrm{K}^{+}$ATPase activity. Although not statistically significant, the activity of the PPP tended to be greater in female embryos than in males, which supports the concept of a greater content of the $\mathrm{X}$-linked enzyme G6PD in female embryos due to the double dose of the gene. Exposure of embryos to $0.01 \mathrm{mg} \mathrm{BCB} / \mathrm{ml}$ increased the relative activity of the PPP without being lethal, indicating that BCB can be used effectively in the study of embryo metabolism.

Financial support was provided by the Ontario Ministry of Agriculture and Food, the Natural Sciences and Engineering Research Council of Canada, and Semex Canada. We thank R. Bériault and S. Manning for management of the animals, W. Johnson and his colleagues in the Dept. of Population Medicine, for collection of the embryos, C. Whitfield, Dept. of Microbiology, for the extensive use of his scintillation counter and D. Porter for his critique of the manuscript.

\section{References}

Avery, B. (1989) Impact of asynchronous ovulations on the expression of sex-dependent growth rate in bovine preimplantation embryos. J. Reprod. Fert. 87, $627-631$.

Benos, D.J. (1981) Ouabain binding to preimplantation rabbit blastocysts. Devl Biol. 83, 69-78.

Benos, D.J. \& Balaban, R.S. (1980) Energy requirements of the developing mammalian blastocyst for active ion transport. Biol. Reprod. 23, 941-947.

Chapman, V.M. \& Shows, T.B. (1976) Somatic cell genetic evidence for X-chromosome linkage of glucose-6phosphate dehydrogenase, phosphoglycerate kinase and hypoxanthine-phosphoribosyl transferase. Nature, Lond. 259, 665-667.

Elsden, R.P., Nelson, L.D. \& Seidel, G.E. (1978) Superovulating cows with follicle stimulating hormone and pregnant mares' serum gonadotrophin. Theriogenology 9, 17-26.

Flood, M.R. \& Wiebold, J.L. (1988) Glucose metabolism by preimplantation pig embryos. J. Reprod. Fert. 84, $7-12$.

Gardiner, C.S., Grobner, M.A. \& Menino, A.R. (1990) Sodium/potassium adenosine triphosphatase $\alpha$ subunit and $\alpha$-subunit mRNA levels in early rabbit embryos. Biol. Reprod. 42, 539-544.

Gardner, D.K. \& Leese, H.J. (1986) Non-invasive measurement of nutrient uptake by single cultured preimplantation mouse embryos. Hum. Reprod. 1, 25-27.

Gardner, D.K. \& Leese, H.J. (1987) Assessment of embryo viability prior to transfer by the non-invasive measurement of glucose uptake. J. exp. Zool. 242, 103-105. 
Gardner, D.K. \& Leese, H.J.(1988) The role of glucose and pyruvate transport in regulating nutrient utilization by preimplantation mouse embryos. Development 104, 423-429.

Gott, A.L., Hardy, K., Winston, R.M.L. \& Leese, H.J. (1990) Non-invasive measurement of pyruvate and glucose uptake and lactate production by single human preimplantation embryos. Hum. Reprod. 5, 104-108.

Iwasaki, S., Shioya, Y., Monji, Y. \& Nakahara, T. (1989) Developmental changes and sex difference in glucose6-phosphate dehydrogenase activity of bovine oocytes and embryos fertilized in vitro. Jpn. J. Anim. Reprod. 3, 198-203.

Kaye, P.L. (1986) Metabolic aspects of the physiology of the preimplantation embryo. In Experimental Approaches to Mammalian Embryonic Development, pp. 267-292. Eds J. Rossant \& R. A. Pederson. Cambridge University Press, Cambridge.

King, W.A., Linares, T., Gustavsson, I. \& Bane, A. (1979) Method for preparation of chromosomes from bovine zygotes and blastocysts. Vet. Sci. Commun. 3, 51-56.

Larrabee, M. (1989) The pentose cycle (hexose monophosphate shunt). Rigorous evaluation of limits to the flux from glucose using ${ }^{14} \mathrm{CO}_{2}$ data, with applications to peripheral ganglia of chicken embryos. $J$. Biol. Chem. 264, 15875-15879.

Lyon, M. (1961) Gene action in the X-chromosome of the mouse. Nature, Lond. 190, 372-373.

Ménézo, Y. \& Khatchadourian, C. (1990) Implication de l'activité glucose 6 phosphate isomérase (EC 5.3.1.9) dans l'arrêt de la segmentation de l'œuf de souris au stade 2 cellules in vitro. C. R. Acad. Sci. Ser III 310, 297-301.

Mittwoch, U. (1989) Sex differentiation in mammals and tempo of growth: probabilities vs. switches. $J$. theor. Biol. 137, 445-455.

Monk, M. (1987) Biochemical microassays for X-chromosome-linked enzymes HPRT and PGK. In Mammalian Development, pp. 139-161. Ed. M. Monk. IRL Press, Oxford.

Monk, M. \& Handyside, A.H. (1988) Sexing of preimplantation mouse embryos by measurement of Xlinked gene dosage in a single blastomere. J. Reprod. Fert. 82, 365-368.

O'Fallon, J.V. \& Wright, R.W., Jr (1986) Quantitative determination of the pentose phosphate pathway in preimplantation mouse embryos. Biol. Reprod. 34, $58-64$.
O'Fallon, J.V. \& Wright, R.W., Jr (1987) Calculation of the pentose phosphate and Embden-Meyerhoff pathways from a single incubation with $\left[\mathrm{U}-{ }^{14} \mathrm{C}\right]-$ and [5- $\left.{ }^{3} \mathrm{H}\right]$-glucose. Ann. Biochem. 162, 33-38.

Rieger, D., Desaulnier, D. \& Goff, A.K. (1988) Ovulatory response and embryo yield in superovulated Holstein heifers given a priming dose of FSH-P at Day-2 of the estrous cycle. Theriogenology 30, 695-699.

Rieger, D. \& Guay, P. (1988) Measurement of the metabolism of energy substrates in individual bovine blastocysts. J. Reprod. Fert. 83, 585-591.

Rieger, D., Palmer, E., Lagneau-Petit, D. \& Tiffin, G. (1989) Simultaneous measurement of the metabolism of two energy substrates in individual horse and cow embryos. Theriogenology 31, 249 (abstr.).

Rieger, D., Bruyas, J.-F., Lagneaux, D., Bézard, J. \& Palmer, E. (in press) The effect of cryopreservation on the metabolic activity of Day-6.5 horse embryos. J. Reprod. Fert. Suppl. 44.

Romagnano, A., Richer, C.L., King, W.A. \& Betteridge, K.J. (1987) Analysis of X-chromosome inactivation in horse embryos. J. Reprod. Fert. Suppl. 35, 353-361.

Sumner, A.T. (1972) A simple technique for demonstrating centromeric heterochromatin. Exp. Cell Res. 75, 304-306.

Telford, N.A., Watson, A.J. \& Schultz, G.A. (1990) Transition from maternal to embryonic control in early mammalian development: a comparison of several species. Molec. Reprod. Devel. 26, 90-100.

Tiffin, G., Rieger, D., Betteridge, K.J., Yadav, B. \& King, W.A. (1990) Measurement of the activity of the pentose phosphate pathway in sexed bovine embryos Theriogenology 33, 339 (abstr.).

West, J.D. (1982) X-chromosome expression during mouse embryogenesis. In Genetic Control of Gamete Production and Function, pp. 49-91. Eds P. G. Crosignani \& B. L. Rubin. Academic Press, London, UK.

Williams, J.J. (1986) A technique for sexing mouse embryos by a visual colorimetric assay of the $\mathrm{X}$ linked enzyme, glucose 6-phosphate dehydrogenase. Theriogenology 25, 733-739.

Wood, T. (1985) The Pentose Phosphate Pathway. Academic Press, Orlando.

Received 20 August 1990 